\title{
PERAN KERENTANAN NORMATIF, KESADARAN NILAI, DAN INTEGRITAS TERHADAP SIKAP DAN MINAT BELI PRODUK BAJAKAN SEPATU BERMEREK
}

\author{
Anas Hidayat (anas.hidayat@uii.ac.id) \\ Ayu Hema Ajeng Diwasasri (ayuhema@ymail.com) \\ Khaerunisa Amalia Sofia (amalia_s_a@yahoo.co)m \\ International Program, Fakultas Ekonomi, Universitas Islam Indonesia
}

\begin{abstract}
Abstrak
Perkembangan fashion yang cepat dan meningkatnya kebutuhan setiap individu menciptakan peluang bagi para produsen. Mereka berlomba-lomba untuk dapat memenuhi kebutuhan setiap konsumennya. Sepatu menjadi salah satu produk yang banyak beredar di pasaran karena dapat dibuat dengan model dan warna yang bermacam-macam, selain itu kegunaanya pun bermacam-macam. Penelitian ini dibuat untuk mengetahui seberapa besar pengaruh kerentanan normatif, nilai kesadaran, dan integritas, berpengaruh terhadap sikap dan minat beli produk bajakan pada mahasiswa Fakultas Ekonomi Universitas Islam Indonesia di Yogyakarta. Penelitian ini melibatkan 200 responden dengan teknik accidental sampling dan angket sebagai alat untuk mengumpulkan data. Hasil penelitian dianalisis dengan metode kualitatif yang meliputi uji goodness of fit index, analisis Structural Equation Modeling (SEM), dan pengujian hipotesis. Hasil analisis menunjukkan bahwa ada pengaruh negatif dan signifikan antara kerentanan normatif dan integritas terhadap sikap pada pembelian produk bajakan. Lebih lanjut, hasil analisis Regresi Linier menunjukkan bahwa ada pengaruh positif dan signifikan antara kesadaran nilai terhadap sikap pada pembelian produk bajakan, serta pengaruh positif antara sikap pembelian produk bajakan terhadapa minat beli konsumen.
\end{abstract}

Kata kunci: kerentanan normatif, nilai kesadaran, integritas, sikap pembelian produk bajakan, minat beli.

\section{PENDAHULUAN}

Di era yang sudah berkembang ini, kebutuhan manusia semakin meluas. Tidak hanya berhenti pada kebutuhan primer seperti sandang, pangan dan papan saja, tetapi juga memiliki kebutuhan yang lebih kompleks terutama dalam hal fashion. Saat ini kebutuhan manusia akan fashion semakin berkembang, baik golongan menengah ke atas maupun golongan menengah ke bawah. Setiap individu ingin memperlihatkan kemampuannya mengikuti perkembangan fashion. Kebutuhan fashion yang semakin meningkat menyebabkan perkembangan perubahan trend semakin cepat.

Salah satu model fashion yang mengalami perkembangan sangat pesat saat ini misalnya, model pakaian, model sepatu, dan model tas. Model sepatu yang disediakan oleh para produsen saat ini juga beraneka ragam dari model untuk anak-anak sampai model untuk orang dewasa, dari harga murah sampai harga yang mahal, dari yang memiliki kualitas rendah, sedang, dan tinggi, bahkan dari produk yang asli sampai produk yang palsu.

Menurut Check dan Easterling(2008), perilaku pembelian konsumen memang merupakan suatu pembahasan yang unik dan menarik, sebab bahasan ini akan menyangkut pada berbagai 
faktor di berbagai dimensi kehidupan manusia yang berbeda-beda. Selama manusia tersebut melakukan kegiatan perekonomian (pembelian) dalam kehidupan, maka selama itu kita akan selalu mendapatkan fenomena-fenomena baru dalam pola perilaku pembeliannya. Salah satu fenomena yang cukup menarik perhatian penulis dan mungkin pula menarik perhatian banyak orang yaitu, fenomena peredaran produk-produk imitasi atau produk palsu, sebagai sebuah alternatif baru dalam pilihan konsumsi konsumen Indonesia. Selain itu, pemalsuan produk fashion sudah dianggap menjadi sebuah epidemik dan merugikan jutaan dollar Amerika bagi industri fashion.

Pemalsuan produk telah ada sejak 1970-an ketika para korban hanya produsen yang lebih dari harga pakaian dan bagasi (Thurasamy et al., 2003). Banyak alasan kenapa seseorang membeli produk fashion palsu. Pembeli produk palsu memberikan alasan bahwa mereka membeli produk palsu, karena hal tersebut tidak memberikan dampak langsung yang merugikan bagi mereka. Harga produk palsu jauh lebih murah sehingga mereka merasa seolah-olah sebagai wise shoppers (pembeli bijaksana) (Hartanto, 2012).

Menurut Shultz et al., dalam Trisdiarto (2012), merek barang mewah mudah dipalsukan karena barang-barang tersebut mudah untuk dijual dan tidak menciptakan biaya produksi yang tinggi. Saat ini merek Sepatu Crocs cukup terkenal dan termasuk sepatu mewah karena, sepatu ini dijual dengan harga cukup tinggi. Maka, merek Sepatu Crocs adalah salah satu produk yang sangat ingin dimiliki masyarakat, khususnya di Negara Indonesia.Konsumen yang membeli produk-produk bermerek kemungkinan dapat dideskripsikan sebagai pemerhati diri dan lebih memerhatikan penampilan (Penz \& Stottinger, 2005). Produk fesyen tiruan membawa image yang tinggi dan prestis yang terhubung melalui nama merk yang sudah terkenal. Kemiripan dalam wujud, kualitas dan image yang direpresentasikan oleh versi tiruan dari sebuah produk dibandingkan dengan yang original diakui lebih penting dalam mempengaruhi sikap beli konsumen (Wee et al., 1995).

Melihat kesuksesan dari perusahaan yang memproduksi sepatu dan sandal dengan merek Crocs, beberapa tahun ini di Indonesia muncul produk palsu atau produk tiruan dengan merek yang sama yaitu Crocs. Pendiri dan pencipta Perusahaan Crocs adalah George B. Boedecker Jr. Awalnya, George hanya ingin mendesain sepatu untuk di spa. Karena, saat spa butuh sepatu yang nyaman, tidak licin, dan sederhana. Sepatu-sepatu Crocs mulai dibuat dengan bermacam-macam jenis dan bentuk. Sepatu Crocs yang pertama dibuat adalah Crocs Beach, Yang hanya diproduksi 200 pasang dan langsung terjual habis saat itu (BLOGdetik, 2013). Karena Sepatu Crocs termasuk produk yang sangat populer di masyarakat khususnya masyarakat Indonesia, maka banyak oknum yang curang dengan membuat Sepatu Crocs yang palsu. Alasan banyak produk palsu Sepatu Crocs karena sepatu ini termasuk sepatu dengan harga tinggi yang rata-rata hanya dimiliki oleh masyarakat menengah ke atas. Dengan begitu, banyak oknum-oknum yang membuat Sepatu Crocs palsu yang sangat mirip aslinya mulai dari bentuk, bahan, dan jenisnya.

Sepatu Crocs palsu banyak diproduksi dengan tujuan agar masyarakat Indonesia menengah ke bawah bisa memiliki Sepatu Crocs ini (Anne Ahira, 2012). Lebih lanjut, ditinjau dari fakta yang ada di lapangan terdapat produk sepatu dan sandal Crocs palsu yang dijual bebas di pasaran, seperti di toko online, gerai yang dibuka di pinggir jalan, dan juga banyak penjual face to face yang menawarkan produk Sepatu Crocs palsu, bahkan di pasar tradisional juga ada yang menjual. Akan tetapi, uniknya di Negara Indonesia banyak sekali konsumen yang berminat untuk membeli sebuah produk yang tidak dijual di outlet yang resmi (Hartanto, 2012). Hal ini mungkin dapat dipahami dengan temuan Assael dalam Tridiastiti (2012) yang 
Anas Hidayat

Ayu Hema Ajeng Diwasasri

Kharunisa Amalia Sofia

menyatakan bahwa minat beli merupakan kecenderungan konsumen untuk membeli suatu merek atau mengambil tindakan yang berhubungan dengan pembelian yang diukur dengan tingkat kemungkinan konsumen melakukan pembelian. Sedangkan sikap adalah bahwa sikap merupakan suatu kecenderungan untuk mendekat atau menghindar, positif atau negatif terhadap berbagai keadaan sosial, apakah itu institusi, pribadi, situasi, ide, konsep dan sebagainya (Ieya, 2012).

Selanjutnya, kerentanan normatif berkaitan dengan pengaruh sosial dan karakteristik kepribadian yang timbul dari keinginan untuk terlihat baik di depan orang lain, ini termasuk pentingnya mengetahui merek yang membuat kesan baik pada orang lain (Ang et al., 2001). Lalu hal lain yang juga mempengaruhi sikap adalah kesadaran nilai yang menurut Lichtenstein dalam Setianto (2012), kesadaran nilai didefinisikan sebagai kesediaan untuk membayar harga yang lebih rendah untuk suatu produk dengan beberapa kekurangan dalam kualitas. Integritas ditentukan oleh standar etika pribadi dan ketaatan kepada hukum. Jika konsumen melihat integritas sebagai elemen penting, kemungkinan mereka melihat barang palsu sebagai sesuatu yang negatif. Akan tetapi, nilai-nilai luhur berubah sesuai berkembangnya jaman (Ang et al., 2001).

Berdasarkan latar belakang dan masalah yang telah dikaji, tujuan penelitian ini terbagi menjadi dua yaitu pertama untuk mengkaji peran variabel kerentanan normatif, nilai kesadaran, integritas, berpengaruh terhadap sikap pembelian produk bajakan. Kedua, untuk menganalisa peranan sikap konsumen atas produk bajakan terhadap minat beli produk bajakan.

\section{KAJIAN PUSTAKA}

Kajian Pustaka ini dimaksudkan untuk mendokumentasikan dan mengkaji hasil penelitian yang pernah ada, penjelasan yang dapat mendukung topik penelitian yang akan dilakukan, serta penjelasan tentang konsep, variabel, indikator, penelitian, pengukuran dan asumsi pada area yang sama.

\section{a) Pembajakan Produk (Product Piracy)}

Menurut Thurasamy et al., (2003), pemalsuan atau pembajakan produk umumnya digunakan untuk menggambarkan pelanggaran yang disengaja terhadap karya cipta atau merek dagang pada skala komersial. Dalam industri musik, pembajakan juga terjadi terhadap penyalinan yang tidak sah yang dapat dikelompokkan menjadi :

1) Simple Piracy: Kegiatan untuk duplikasi yang tidak sah dari dokumen asli merekam untuk keuntungan komersial tanpa persetujuan dari pemilik. Kemasan dari bajakan salinan berbeda dari yang asli. Versi bajakan sering kompilasi, seperti sebagai "greatest hits" dari artis tertentu, atau koleksi genre tertentu atau "Populer dangduts" dan sebagainya.

2) Counterfeits : Produk yang disalin dan dikemas menyerupai asli dengan sedekat mungkin. Merek dagang produsen asli dan logo yang direproduksi lalu ditempel pada kemasan untuk menyesatkan konsumen dan membuat percaya bahwa mereka membeli produk asli. 
3) Bootlegs : Bentuk rekaman tidak sah dari pertunjukan live atau siaran. Mereka disalin dan dijual seringkali dengan harga premium tanpa izin dari penyanyi, komposer atau perusahaan rekaman.

Menurut Gentry et al., dalam Setianto (2012), sejumlah peneliti berpendapat bahwa permintaan konsumen untuk produk bajakan adalah salah satu penyebab utama dari keberadaan dan peningkatan pertumbuhan fenomena pembajakan. Sebagai akibat langsung dari argumen ini, cukup banyak penelitian telah difokuskan pada mengidentifikasi faktor penting yang mempengaruhi sikap konsumen terhadap produk bajakan.

\section{b) Kerentanan Normatif (Normative Susceptibility)}

Kerentanan normatif harus dilakukan dengan keputusan pembelian yang tidak didasarkan pada pendapat orang lain, tetapi pada harapan apa yang akan mengesankan orang lain karena konsumen dengan kerentanan normatif kemungkinan membuat keputusan berdasarkan ekspektasi atas apa yang dapat mengesankan orang lain(Ang et al., 2001).Hal ini didasarkan pada premis bahwa jika membeli palsu tidak membuat kesan yang baik pada orang lain sementara memproyeksikan citra yang baik adalah penting, dan sikap dalam membeli produk bajakan akan kurang menguntungkan. Dengan demikian, kerentanan normatif turut serta dalam pengambilan keputusan membeli produk palsu (Thurasamy et al., 2003). Berdasarkan kajian diatas hipotesis pertama dirumuskan:

H1:Kerentanan normatif berpengaruh negatif terhadap sikap pembelian produkbajakan.

\section{c) Kesadaran Nilai (Value Consciousness)}

Lichtenstein et al.(1990), mendefinisikan kesadaran nilai sebagai kesediaan konsumen membayar harga yang lebih rendah dengan tetap menyadari adanya beberapa kekurangan pada kualitas. Karena, produk palsu telah memberikan penghematan biaya yang besar kepada konsumen dengan beberapa kompromi yang dapat diterima dalam kualitas, namun, nilai itu dianggap sudah tinggi (Thurasamyet al., 2003).

Kesadaran nilai ini terkait dengan harga produk dan sejauh mana konsumen merasakan bahwa nilai produk setara dengan nilai untuk kosumen. Penelitian sebelumnya menguji hubungan antara kesadaran nilai dan pertimbangan etika tetapi tidak menemukan hubungan yang signifikan antara keduanya. Namun demikian, kesadaran nilai merupakan kunci dalam pengambilan keputusan pembelian oleh konsumen (Hartanto, 2012).

Dalam hal ini, penelitian akan mengharapkan nilai lebih sadar konsumen untuk memiliki lebih menguntungkan sikap membeli produk bajakan relatif terhadap mereka yang nilai kurang sadar. Dengan demikian hipotesis kedua dapat dinyatakan sebagai:

H2:Kesadaran nilai berpengaruh positif terhadap sikap pembelian produk bajakan.

\section{d) Integritas (Integrity)}

Integritas dinyatakan memilikki pengaruh signifikan yang kuat terhadap konsekuensi sosial dari sikap konsumen atas produk tiruan. (Phau dan Teah, 2009). Selain itu jika konsumen memandang integritas sebagai sesuatu yang kritis, maka kesempatan bagi mereka untuk menganggap produk tiruan sebagai sebuah alternatif kecil, akan tetapi jika konsumen tidak 
merasa bahwa integritas itu penting maka mereka tidak akan merasa bersalah untuk menggunakan produk tiruan ( Ang et al., 2001; Wang et al., 2005).

Dalam banyak kasus, konsumen lebih cenderung untuk merasionalisasi perilaku mereka yang tidak etis, mengganggap bahwa itu hal yang benar. Oleh karena itu, diharapkan bahwa mereka yang menghargai integritas akan memiliki respon yang kurang signifikan terhadap sikap atas produk bajakan (Thurasamyet al., 2003). Dengan demikian hipotesis ketiga dapat dinyatakan sebagai berikut:

H3:Integritas berpengaruh negatif terhadap sikap pembelian produk bajakan.

\section{e) Minat Beli (Intention to Buy)}

Menurut Jalal dalam Listyoningrum (2013), minat digambarkan sebagai faktor-faktor motivasional yang mempengaruhi perilaku dan untuk menunjukkan besar usaha yang dikerahkan seseorang untuk bersedia mencoba atau melakukan suatu perilaku.

Minat beli timbul setelah adanya proses evaluasi alternatif dan didalam proses evaluasi, seseorang akan membuat suatu rangkaian pilihan mengenai produk yang hendak dibeli atas dasar merek maupun minat. Minat mencerminkan kemauan seseorang untuk melakukan tindakan tertentu. Minat merupakan variabel antara yang menyebabkan perilaku dari beberapa faktor yang mendukungnya. Faktor-faktornya adalah adanya faktor sosial dan karakteristik kepribadian (Kotler, 1997).

\section{f) Sikap terhadap pembelian produk bajakan (Attitude toward pirated products)}

Menurut Alam dan Sayuti dalam Setianto (2012), sikap adalah kepercayaan positifatau negatif untuk menampilkan suatu perilaku tertentu. Seorang individu akan berniat untuk menampilkan suatu perilaku tertentu ketika ia menilainya secara positif. Sikap ditentukan oleh kepercayaan-kepercayaan individu mengenai konsekuensi dari menampilkan suatu perilaku (behavioral beliefs), daripada berdasarkan hasil evaluasi terhadap konsekuensinya (outcome evaluation).

Menurut Kinnear dan Taylor dalam Listyoningrum (2013), sikap adalah proses yang berorientasikan tindakan, evaluatif, dasar pengetahuan, dan persepsi abadi dari seseorang individu berkenaan dengan suatu obyek atau penemuan. Secara umum, sikap dianggap mempunyai tiga komponen utama yaitu :

1) Komponen Kognitif: Komponen kognitif mengacu pada kesadaran responden dan pengetahuannya terhadap beberapa obyek atau fenomena.

2) Komponen Afektif: Komponen afektif mengacu pada preferensi dan kesenangan responden terhadap obyek atau fenomena.

3) Komponen Perilaku: Komponen perilaku mengacu pada perilaku pembeli yang berupa niat membeli dan membeli.

Menurut Suprapti dalam Trisdiarto (2012), sikap merupakan suatu ekspresi perasaaan seseorang yang merefleksikan kesukan atau ketidaksukaannya terhadap suatu obyek. Karena sikap seseorang merupakan hasil dari suatu proses psikologis, maka hal itu tidak dapat diamati secara langsung tetapi harus disimpulkan dari apa yang dikatakan atau dilakukannya. Seperti halnya, terhadap produk bajakan yang banyak beredar saat ini. Dalam konteks produk 
bajakan evaluasi konsumen dari produk bajakan tersebut akan mengenal produk, konsumen akan melakukan tahap pembelian, sebaik apa dia menerima persetujuan tentang perilaku tersebut dari kelompoknya. Setelah pembelian produk, konsumen akan mengalami tingkat kepuasan atau ketidakpuasan tertentu. Kepuasan konsumen akan terpenuhi apabila proses penyampaian jasa dari si pemberi jasa kepada konsumen sesuai dengan apa yang dipersepsikan konsumen (Thurasamy et al., 2003). Dengan demikian hipotesis ketiga dapat dinyatakan sebagai berikut:

H4: Sikap pembelian produk bajakan berpengaruh positif terhadap minat beli produk bajakan.

\section{METODE PENELITIAN}

Metode penelitian merupakan seluruh rangkaian kegiatan yang akan dilakukan untuk membuktikan atau menyanggah hipotesis yang telah dirumuskan, serta menjawab pertanyaan penelitian seperti yang telah dirumuskan pada rumusan masalah. Untuk menjawab masalah penelitian dan membuktikan hipotesis diperlukan fakta lapangan (data empiris) dari hasil penelitian.

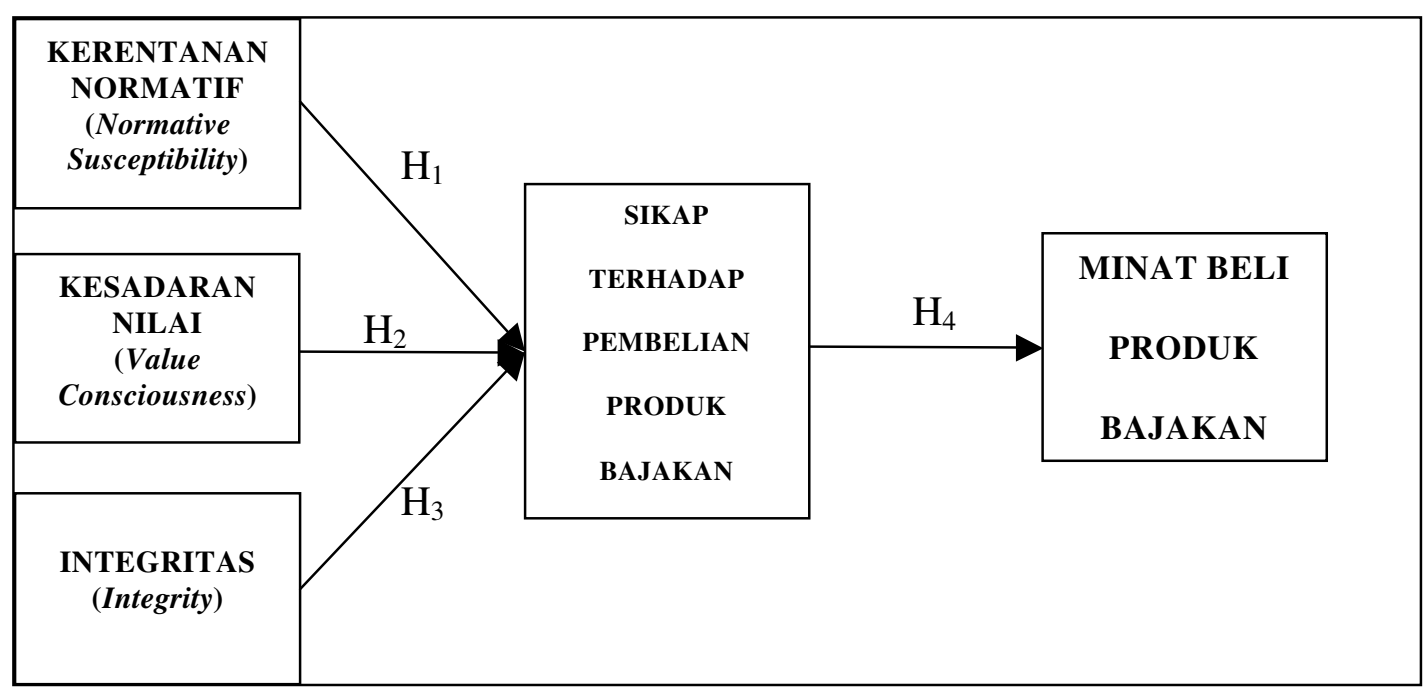

\section{Gambar 1 \\ Kerangka Penelitian \\ (Thurasamy, 2003)}

Populasi penelitian adalah seluruh mahasiswa di daerah Sleman, Yogyakarta. Sedangkan, sampel penelitian adalah mahasiswa Fakultas Ekonomi Universitas Islam Indonesia yang setidaknya pernah menggunakan produk bajakan sepatu Crocs.

Penelitian ini melibatkan 200 responden dengan teknik accidental sampling. Metode pengumpulan data menggunakan angket yang disusun menggunakan skala Likert, dengan skor 1 menunjukkan "sangat tidak setuju" dan skor 5 menunjukkan "sangat setuju". Angket terdiri dari enam bagian, bagian satu berisi pertanyaan mengenai informasi demografi responden, bagian dua memuat pertanyaan mengenai kerentanan normatif, bagian tiga memuat pertanyaan mengenai kesadaran nilai, bagian empat memuat pertanyaan mengenai integritas, bagian lima memuat pertanyaan mengenai sikap terhadap produk bajakan, dan bagian enam memuat pertanyaan mengenai minat beli ptoduk bajakan. Selanjutnya, 
pembahasan analisis hasil penelitian ini dimulai dari analisis kualitatif yang meliputi uji goodness of fit index, analisis Structural Equation Modeling (SEM), dan pengujian hipotesis dengan bantuan program statistik komputer AMOS versi 16.0.

\section{HASIL PENELITIAN}

Analisis measurement model pada dasarnya adalah untuk menguji unidimensionalitas dari indikator-indikator yang menjelaskan sebuah faktor atau sebuah variabel laten. Evaluasi yang dipakai untuk tujuan tersebut adalah melihat nilai $t$ hitung dari parameter dan nilai signifikansinya. Holmes-Smith (2001) menyatakan bahwa pada $\alpha=0,05$ parameter yang memiliki nilai $t \geq 1,96$ menunjukkan parameter tersebut signifikan atau valid. Disamping itu nilai signifikansi dibawah 0,05 juga menunjukkan parameter tersebut signifikan merupakan unidimensionalitas dari suatu faktor yang diuji.

Berdasarkan hasil dari penelitian setelah dilihat dari nilai $t$ dan tingkat signifikan masingmasing indikator semuanya dinyatakan valid. Selain itu, hasil pengujian terhadap goodnes of fit model yang digunakan dalam penelitian diringkas dalam tabel 2, berikut:

Tabel 1:

Hasil Goodness of Fit Index

\begin{tabular}{|l|l|l|l|}
\hline Goodness of Fit & \multicolumn{1}{|c|}{ Nilai } & Cut-off Value & Keterangan \\
\hline Chi-Square $\left(\chi^{2}\right)$ & 438,696 & Diharapkan kecil & Baik \\
Probability & 0,078 & $\geq 0,05$ & Baik \\
RMSEA & 0,052 & $\leq 0,08$ & Baik \\
GFI & 0,920 & $\geq 0,90$ & Baik \\
CMN/DF & 1,102 & $\leq 2,00$ & Baik \\
TLI & 0,975 & $\geq 0,95$ & Baik \\
CFI & 0,994 & $\geq 0,95$ & Baik \\
\hline
\end{tabular}

Sumber: data primer diolah, 2013

Berdasarkan pada Tabel 1 hasil uji normalitas bahwa nilai RMSEA $<$ nilai kritisnya $=0,080$, GFI $>0,90$, dan TLI dan CFI $\geq 0,90$. Hal ini berarti model persamaan structural dalam penelitian ini adalah fit (memiliki kesesuaian).

Peneliti menguji validitas setiap observed variable atau indikator dengan pendekatan convergent validity. Validitas konvergen dapat dilihat dari measurement model dengan menentukan apakah setiap indikator yang diestimasi secara valid mengukur dimensi dari konsep yang diujinya. Sebuah indikator menunjukkan validitas konvergen yang signifikan apabila koefisien variabel indikator itu lebih besar dari dua kali standard error-nya (Anderson dan Gerbing, 1988) atau memiliki critical ratio yang lebih besar dari dua kali standard error-nya (Ferdinand, 2002).Kriterianya adalah apabila $t$ value indikator $\geq 1.96$ maka indikator tersebut signifikan pada tingkat $\alpha=0,05$ (Holmes, 2001).

Selanjutnya, Joreskog dan Sorbom (1996) menambahkan bahwa indeks GFI $\geq 0,90$ menunjukkan bahwa indikator-indikator yang diukur adalah valid dan merupakan unidimensionalitas dari konstruk yang diuji. Dari semua penghitungan CFA sebagaimana telah diulas pada sub bab penilaian goodness of fit dan modifikasi model tampak bahwa 
semua Composite yang diuji yaitu: loyalitas konsumen, sikap pada pembelian produk bajakan, kepercayaan konsumen, dan integritas, semuanya memiliki indeks GFI $>0,90$.

Tabel 2:

Hasil Uji Reliabilitas Item-item Variabel Penelitian

\begin{tabular}{|l|l|r|r|r|r|r|}
\hline & & Loading & Error & Loading & Error & $\begin{array}{l}\text { Construct } \\
\text { Reliability }\end{array}$ \\
\hline NS1 & Normative_Susceptibility & 0.691 & 0.689 & 15.984 & 2.283 & 0.875 \\
VC1 & Value_Consciousness & 0.673 & 0.613 & 11.323 & 2.957 & 0.793 \\
I1 & Integrity & 0.643 & 0.559 & 49.112 & 5.183 & 0.905 \\
ATT1 & Attitude & 0.623 & 0.450 & 13.242 & 1.940 & 0.872 \\
IB1 & Intention_to_Buy & 0.593 & 0.611 & 17.464 & 1.286 & 0.931 \\
\hline
\end{tabular}

Sumber: data primer diolah, 2013

Berdasarkan Tabel 2 tersebut di atas dapat diketahui bahwa nilai korelasi $>0,50$, sehingga seluruh pertanyaan dalam kuesioner pada item-item pertanyaan pada variabel kerentanan normatif, nilai kesadaran, dan integritas, sikap pembelian pada produk bajakan, dan minat beli produk bajakanadalah valid. Nilai koefisien Composite Reliability> 0,60 sehingga seluruh pertanyaan dalam kuesioner pada item-item pertanyaan variabel kerentanan normatif, nilai kesadaran, dan integritas, sikap pembelian pada produk bajakan, dan minat beli produk bajakanadalah reliabel.

Hasil pengujian terhadap model penelitian dapat digambarkan dalam tabel hasil estimasi Structural Equation Model (SEM)sebagai berikut:

Tabel 3:

Hasil Estimasi Structural Equation Model (SEM)

\begin{tabular}{|c|c|c|c|c|c|c|}
\hline Hipotesis & Variabel & $\begin{array}{c}\text { Koefisien } \\
\text { Regresi }\end{array}$ & $\begin{array}{c}\text { Standart } \\
\text { Error }\end{array}$ & t-hitung & $\begin{array}{c}\text { Prob. } \\
(\boldsymbol{\alpha}=\mathbf{5 \%})\end{array}$ & Ket. \\
\hline H1 & NS-ATT & $-0,389$ & 0,055 & $-4,664$ & 0,000 & Diterima \\
\hline H2 & VC-ATT & 0,290 & 0,060 & 3,755 & 0,000 & Diterima \\
\hline H3 & I-ATT & $-0,325$ & 0,060 & $-4,163$ & 0,000 & Diterima \\
\hline H4 & ATT-I & 0,412 & 0,100 & 4,630 & 0,000 & Diterima \\
\hline
\end{tabular}

Sumber: data primer diolah, 2013 


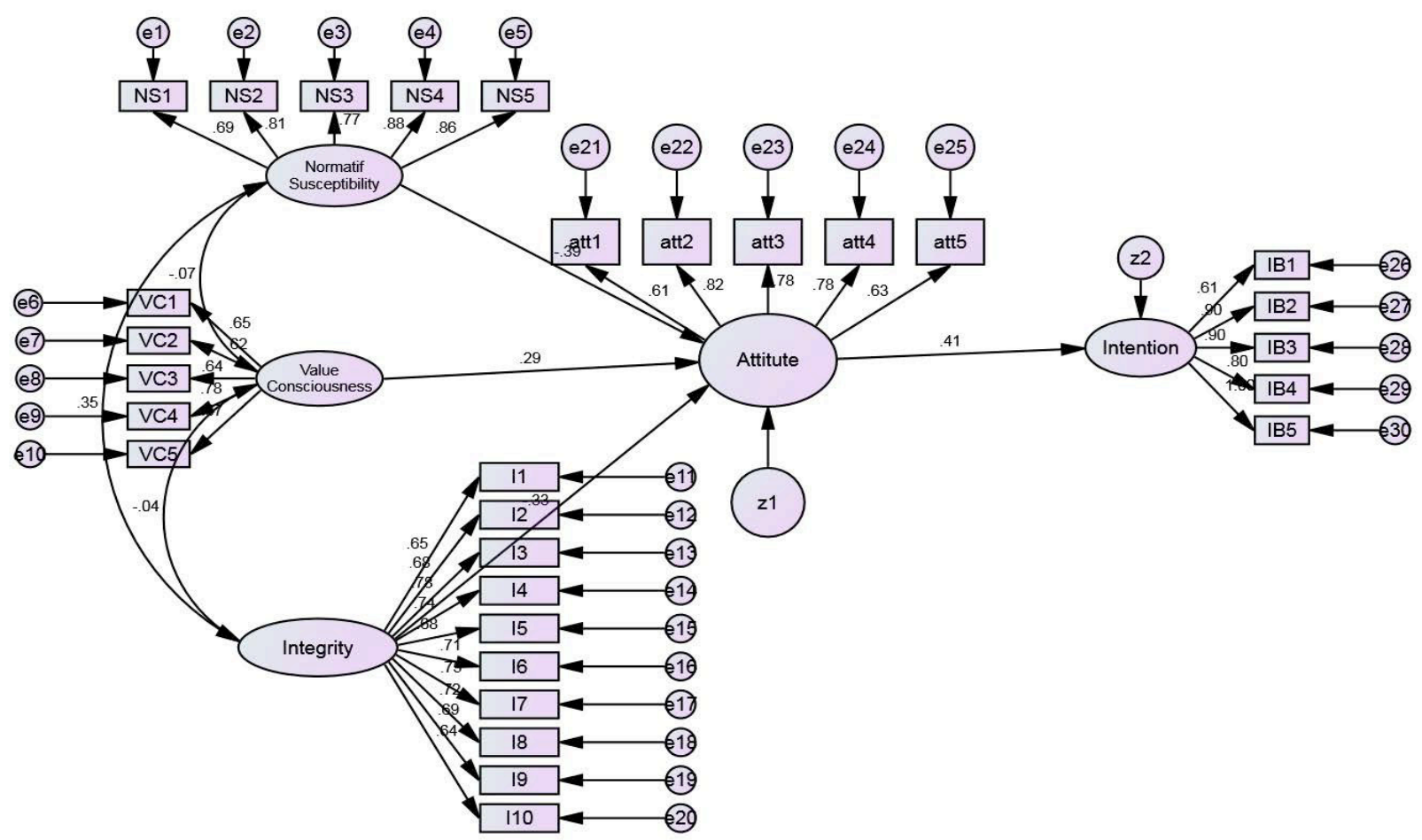

Gambar 2:

Model Persamaan Struktural

Berdasarkan Tabel 3, hasil perhitungan mengindikasikan bahwa nilai probabilitas $\mathrm{p}=0,000<$ 0,05 , sehingga semua variabel berpengaruh. Tetapi, 2 berpengaruh negatif dan 2 berpengaruh positif.

\section{PEMBAHASAN}

Hasil uji hipotesis menunjukkan bahwa ada pengaruh negatif dan signifikan antara kerentanan normatif terhadap sikap pada pembelian produk bajakan. Hal ini dapat diartikan, jika semakin tinggi kerentanan normatif, yang berarti semakin tinggi pula keinginan untuk mengesankan orang lain, maka akan semakin rendah kecenderungan seseorang untuk menggunakan produk bajakan. Kerentanan normatif dipengaruhi oleh keputusan pembelian yang tidak didasarkan pada pengetahuan dan informasi cukup yang didapat konsumen, tetapi pada harapan akan apa yang akan mengesankan orang lain. Oleh karena itu, seseorang dengan kerentanan normatif tinggi tidak akan membeli ataupun memakai produk bajakan karena produk bajakan tidak akan mampu mengesankan orang lain..

Lalu, hasil uji hipotesis juga menunjukkan bahwa ada pengaruh positif dan signifikan antara kesadaran nilai terhadap sikap pada pembelian produk bajakan. Hal ini dapat diartikan, jika kesadaran nilai konsumen itu tinggi maka akan semakin baik sikap konsumen terhadap produk bajakan dan pembelian produk bajakan. Kesadaran nilai dapat dipahami dengan kesadaran konsumen akan nilai suatu barang, yakni dimana harga rendah yang dibayarkan konsumen akan setara dengan kualitas rendah yang nantinya didapat. Namun, kualitas dari barang bajakan sudah dianggap cukup tinggi bagi konsumen dan sebanding dengan harga yang dibayarkan. Nilai adalah keyakinan abadi bahwa modus perilaku tertentu atau keadaanakhir eksistensi adalah lebih baik untuk mode yang berlawanan dari perilaku atau end-state 
(Rokeach, 1973). Nilai telah terbukti dapat membentuk sikap konsumen dan perilaku dalam berbagai situasi, termasuk pembelian alami makanan, pemberian hadiah, pilihan item fashion dan konsumsi kegiatan olahraga (Kropp et al., 2005).

Selanjutnya, hasil uji hipotesis menunjukkan bahwa ada pengaruh negatif dan signifikan antara integritas terhadap sikap pada pembelian produk bajakan. Sesuai dengan hasil uji hipotesis, konsumen yang memiliki integritas tinggi maka akan cenderung menjauhi produk bajakan karena integritas yang tinggi akan membuat konsumen menganggap bahwa pembajakan produk itu hal yang tidak pantas. Penelitian telah menunjukkan bahwa dimana konsumen standar etika yang rendah, mereka cenderung merasa bertanggung jawab untuk pembelian produk bajakan. Dalam kebanyakan kasus, mereka lebih cenderung untuk merasionalisasi perilaku mereka tidak etis. Oleh karena itu, diharapkan bahwa mereka yang menghargai integritas akan memiliki kecenderungan menolak produk bajakan (Thurasamy et al., 2003).

Sementara itu, adanya pengaruh positif dan signifikan antara sikap pada pembelian produk bajakan terhadap minat beli konsumen pada produk palsu juga telah dibuktikan dengan hasil uji hipotesis pada penelitian ini. Sehingga apabila individu memiliki sikap yang positif terhadap suatu obyek, ia akan siap membantu, memperhatikan, dan berbuat sesuatu yang menguntungkan obyek itu. Secara logika berpikir bahwa sikap yang baik akan cenderung diikuti dengan minat beli yang tinggi pula. Menurut Hini et al., dalam Trisdiarto (2012), sikap sering diyakini penting untuk pemasaran karena adanya kausal yang diasumsikan dihubungkan antara sikap, niat dan perilaku. Lebih lanjut, sikap positif akan menghasilkan niat yang lebih tinggi untuk melakukan perilaku (Ang et al., 2001), akibatnya, orang bisa berharap bahwa sikap membeli produk bajakan menjadi prediktor niat untuk membeli produk bajakan (Thurasamy et al., 2003).

\section{PENUTUP}

Hasil dari penelitian ini telah membuktikan hipotesis-hipotesis yang telah ditetapkan pada penelitian ini dan juga mendukung hasil bukti dari penelitian sebelumnya. Bahwa, kerentanan normatif, nilai kesadaran, dan integritas adalah aspek dari aspek sosial dan aspek personal yang dapat mempengaruhi sikap pembelian konsumen terhadap sepatu bermerek mewah yang bajakan. Walaupun penelitian ini telah melakukan survey dengan kuesioner namun penelitian ini masih memiliki kelemahan. Selain sampel yang digunakan sedikit, pemilihan tempat dalam menyebarkan kuesioner masih kurang beragam. Mungkin kedepannya jika dilakukan penelitian serupa dapat memilih lokasi pengambilan kuesioner yang lebih beragam (toko-toko yang menjual produk sepatu bermerek mewah tiruan, toko online, penjual personal di pinggir jalan, dsb), sehingga responden yang ditemui dapat lebih bervariasi.

Dari hasil penelitian ini, karena semakin banyak dan mudah ditemukan sepatu bermerek mewah tiruan ini dijual dengan bebas, namun ada pula sepatu dengan merek lokal yang kualitasnya tidak kalah bagus atau bahkan lebih bagus yang juga marak beredar. Penulis menyarankan akan lebih baik jika kita memulai menggunakan sepatu dengan merek lokal tanpa harus menggunakan merek mewah namun tiruan. Sehingga perdagangan tas bermerek mewah tiruan ini dapat berkurang dan dapat meningkatkan penjualan produk tas lokal. Dan jika ada penulis baru, agar menggunakan aspek-aspek sosial dan personal yang lebih bervariasi. Tidak hanya membahas tentang kerentanan normatif, nilai kesadaran, dan integritas yang mempengaruhi sikap pembelian konsumen terhadap sepatu bermerek mewah 
Anas Hidayat

Ayu Hema Ajeng Diwasasri

Kharunisa Amalia Sofia

yang bajakan. Sehingga, pembaca bisa mendapatkan ilmu tentang sikap produk bahkan secara lebih luas.

Disarankan juga untuk praktisi bisnis dan pemasar produk original agar lebih berani untuk berkampanye secara langsung melawan peredaran produk palsu untuk meningkatkan kesadaran konsumen, juga agar pemasar dapat melakukan diferensiasi produk sehingga dapat menyasar segmen yang lebih luas. Di sisi lain, peranan pemerintah Indonesia khususnya, juga sangat penting untuk menekan laju peredaran produk bajakan. Pemerintah diharapkan mampu melaksanakan hukuman yang sesuai dengan peraturan perundangan terhadap pelaku penjual dan pelaku yang memproduksi produk sepatu palsu karena mereka juga tidak membayar pajak dan merugikan perusahaan pembuat produk asli, sehingga perusahaan pembuat produk asli dapat bertahan dan tidak mengalami kebangkrutan.

\section{DAFTAR PUSTAKA}

Anderson, J.C. dan Gerbing, D.W. 1984.The Effect of Sampling Error on Convergentr, Improper Solution, and Goodness of fit Indices for Maximum Likelihood Factor Analysis. Psychometrica, hal.49.

Ahira, A. 2012. Fenomena Sandal Crocs. diakses dari http:/www.anneahira.com/sandal_crocs.htm pada tanggal 2/4/2013 pukul 15.00 WIB

Ang, S.H., P.S. Cheng, E.A.C. Lim, \& S.K. Tambyah. 2001.Spotthe difference: Consumer responses towards counterfeits.Journal of Consumer Marketing, Vol. 18, No.3, hal. 219-233.

BLOG detik. 2013. Sejarah Crocs. Diakses dari http://crocsmodelterbaru.blogdetik.com/2013/01/03/sejarah-sandal-crocs/ pada tanggal 2/6/13 pukul 19.00 WIB

Check, W. K.dan Easterling, C. R 2008.Fashion Counterfeiting : ConsumerBehavior Issues, Journal of Family and Consumer Sciences :Academic Research Library, Vol. 100, No. 4, hal. 40

Ferdinand A. 2002.Structural Equation Modelling Dalam Peneltian Manajemen. Edisi 2, Seri Pustaka Kunci 03/BP UNDIP

Hartanto, P.H. 2012.Pengaruh Etika Konsumen, Risiko Keuangan, Dan Nilai Kesadaran Terhadap Sikap Pada Produk Bajakan Serta Tanggapan Paska Pembelian Produk Bajakan Jeans Wrangler (Skripsi), Yogyakarta, Fakultas Ekonomi Universitas Islam Indonesia, (Tidak Dipublikasikan)

Holmes. 2001.The Search for the Secure Base: Attachment Theory and Psychotherapy, First Publish, by Brunner-Routledge, 27 Church Road,Hove, East, Sussex BN3 2FA 
Ieya. 2012.Pengertian Sikap. diakses dari http://christyawati.blogspot.com/2012/11/11pengertian-sikap.html pada tanggal 21/5/2013 pukul $21.00 \mathrm{WIB}$

Jalal, A.F.M. 2009.Consumer's Attitude and Consumption of Fish in Dhaka City : Influence of Perceived Risk, Trust and Knowledge, diperoleh pada 23 Juni 2012 di http://munin.uit.no/bitstream/handle/10037/2472/thesis.pdf?sequence=1.

Kotler, P. 1997.Manajemen Pemasaran, Analisis, Implementasi dan Kontrol, Jilid 1 Edisi Bahasa Indonesia, Jakarta: Prenhallindo

Kropp, Fredric, Anne M Lavack, David H Silvera. 2005.Values and collective self-esteem as predictors of consumer susceptibility to interpersonal influence among university students. International Marketing Review, Vol.22, No. 1, hal. 7

Lischtenstein, D.R., R. Netemeyer,\& S. Burton (1990) Distinguishing Coupon Proness from Value Consciousness; an acquisition-transaction utility theory perspective. Journal of Marketing, Vol. 54(July), hal. 54-67.

Listyoningrum, A. 2013. Analisis Minat Beli Konsumen Muslim Terhadap Produk Breadtalk Yang Tidak Diperpanjang Sertifikat Halalnya (Skripsi), Yogyakarta, Fakultas Ekonomi Universitas Islam. Indonesia, (Dipublikasikan)

Penz, E., \& Stöttinger, B. (2005). Forget the "real" thing-take the copy! An explanatory model for the volitional purchase of counterfeit products. Advances in ConsumerResearch. 32(1). 568-575.

Phau, I., and Teah, M. (2009). Devil wears (counterfeit) Prada: a study of antecedents and outcomes of attitudes towards counterfeits of luxury brands. Journal of Consumer Marketing. 26 (1). 15-27.

Rahman, A. 2007.Berbagi Ilmu, Cerita, dan Pengalaman . Diakses dari http://safrilblog.wordpress.com/ pada tanggal 10/3/2013 pukul $12.00 \mathrm{WIB}$

Rokeach, M. 1973.The Nature of Human Values. New York: Free Press

Setianto, D.B. 2012.PengaruhEtika Konsumen, Risiko Keuangan,Dan Nilai Kesadaran Pada SikapTerhadapProduk Bajakan Dan Minat Beli Konsumen TerhadapProduk Bajakan (Skripsi),Yogyakarta, Fakultas EkonomiUniversitasIslam Indonesia,(Tidak Dipublikasikan)

Thurasamy, R., Mohammad, O., Jantan, M., Chow, J. L. W. And Nasirin, S. 2003. Counterfeit Music CDs : Social And Personality Influences, Demographics, Attiudes And Purchase Intention : Some Insights From Malaysia, Journal of Personality and Social Psychology, Vol.51, No.6. 
Tridiastiti, A. 2012.Analisis Pengaruh Kesesuaian Harga-Kualitas, Efek Sosial, Loyalitas Merek, Masalah Etika Terhadap Minat Beli Produk Tas Bermerek Mewah Tiruan Di Yogyakarta (Skripsi), Yogyakarta, Fakultas Ekonomi Universitas Islam. Indonesia, (Tidak Dipublikasikan)

Trisdiarto, T.H. 2012.Pengaruh Faktor Sosial Dan Personal Terhadap Sikap Dan Niat Beli Konsumen Untuk Barang Fashion Palsu Di Kota Denpasar Dan Kabupaten Bandung (Tesis), Denpasar, Program Pascasarjana Universitas Udayana, (TidakDipublikasikan)

Wang, F., Zhang, H., Zang, H. and Ouyang, M. 2005. Purchasing pirated software: an initial examination of Chinese consumers. Journal of Consumer Marketing. 22 (6). 340-51. (http://wenku.baidu.com/view/64c2f9a9b0717fd5360cdc40.html)

Wee, C.-H., Tan, S.-J., \& Cheok, K.-H. 1995. Non-price determinants of intention to purchase counterfeit goods. International Marketing Review. 12(6). 19. 


\section{Lampiran 1.}

\section{Variabel Operasional Penelitian}

\section{Kerentanan Normatif (Normative Suscepbility)}

1) Norma atau hukum yang dibentuk.

2) Minimnya kerentanan normatif menjadi tingginya pelanggaran norma.

3) Bertambahnya pembelian pada produk bajakan.

4) Keinginan untuk selalu menjadi pusat perhatian.

\section{Kesadaran Nilai (Value Consciousness)}

1) Kesadaran akan trend konsumen.

2) Kesadaran perilaku konsumen.

3) Kesadaran konsumen terhadap perbedaan kualitas produk.

\section{Integritas (Integrity)}

1) Memahami dan mengenali perilaku sesuai kode etik.

2) Melakukan tindakan yang konsisten dengan nilai (values) dan keyakinanya.

3) Bertindak berdasarkan nilai (values) meskipun sulit untuk melakukan itu.

4) Bertindak berdasarkan nilai (values) walaupun ada resiko atau biaya yang cukup besar.

Sikap terhadap Pembelian Produk Bajakan (Attitude toward buying pirated product)

1) Pada umumnya membeli produk bajakan adalah pilihan yang baik.

2) Berdasarkan harganya, lebih menyukai produk bajakan.

3) Ketertarikan pada desain produk bajakan.

4) Membeli produk bajakan lebih menguntungkan bagi konsumen.

5) Tidak ada yang salah dari membeli produk bajakan.

\section{Minat Beli Produk Bajakan (Intention to Buy)}

1) Intensitas membeli produk bajakan.

2) Minat membeli produk bajakan.

3) Mempertimbangkan membeli produk bajakan.

4) Mencari informasi ketika akan membeli produk bajakan. 